\title{
Influence of Different Formulations of Tacrolimus on Dosage Regimen and Drug Exposure Within the First Year After Kidney Transplantation
}

\author{
Nikola Z. Stefanović ${ }^{1}$, Tatjana P. Cvetković ${ }^{2,3}$, Katarina S. Dinić ${ }^{4}$, \\ Branka P. Mitić ${ }^{2,5}$, Goran J. Paunović ${ }^{2}$, Ivana D. Damnjanović ${ }^{1}$, \\ Aleksandra K. Catić-Đorđević ${ }^{1}$, Radmila M. Veličković-Radovanovićc ${ }^{1,2}$ \\ ${ }^{1}$ Department of Pharmacy, Faculty of Medicine, University of Niš, Niš, Serbia \\ ${ }^{2}$ Clinic of Nephrology, Clinical Center Niš, Niš, Serbia \\ ${ }^{3}$ Department of Biochemistry, Faculty of Medicine, University of Niš, Niš, Serbia \\ ${ }^{4}$ Faculty of Medicine, University of Niš, Niš, Serbia \\ ${ }^{5}$ Department of Internal Medicine, Faculty of Medicine, University of Niš, Niš, Serbia
}

\section{SUMMARY}

Introduction: Two most common pharmaceutical formulation of tacrolimus (Tac) used after kidney transplantation (Tx) are immediate-release one, administered twice-daily (TacTD), and prolonged-release one, administered once-daily (Tac-OD).

Aim: The aim of this study was to compare daily doses, trough concentrations $\left(C_{0}\right)$ and dose-adjusted trough concentrations $\left(C_{0} / D\right)$ of Tac between patients who administered different drug formulations, Tac-TD or Tac-OD, during the first year after Tx. Additionally, the aim of the study was to compare the distribution of $\mathrm{C}_{0}$ within and beyond the target therapeutic range $(8-12 \mathrm{ng} / \mathrm{mL}$ for the first 90 days and $6-10 \mathrm{ng} / \mathrm{mL}$ afterwards) after the administration of different drug formulations.

Subjects and Methods: A retrospective pharmacokinetic study included 84 patients ( 56 on Tac-TD and 28 on Tac-OD), with a follow-up period between the first and twelfth month post-transplantation. Following pharmacokinetic data were used: daily dose, daily dose according to patient's body weight, concentration $C_{0}$ and $C_{0} / D$ of Tac.

Results: The results of the study showed that patients on TaC-OD formulation had higher daily doses and higher $C_{0}$ during 4-6 months $(p<0.01)$ and 7-12 months $(p<0.01)$ after Tx. Patients on Tac-OD had lower $C_{0} / D$ during 4-6 months $(p<0.05)$ and 7-12 months $(p<0.01)$ after Tx. $C_{0}$ in Tac-TD patients was significantly more frequently below the target range, whereas in Tac-OD patients $C_{0}$ was more frequently above the target range, while both patient groups had equal distribution of $C_{0}$ within the target range of Tac in the period between $4^{\text {th }}$ and $12^{\text {th }}$ month post-transplantation $(p<0.01)$.

Conclusions: The conducted research suggests that patients on Tac-OD preparation may require higher daily doses of Tac compared to patients on Tac-TD preparation in order to maintain optimal immunosuppression in the late post-transplant period.

Keywords: tacrolimus, therapeutic drug monitoring, pharmacokinetic analysis, prolonged-release formulation 


\section{INTRODUCTION}

Kidney transplantation $(\mathrm{Tx})$ is the best treatment option for patients with end-stage renal disease (ESRD), whereby successful Tx provides better quality of life and longer survival compared to dialysis [1]. Immunosuppressive drugs are used to suppress immune response by preventing acute rejection in the early period after Tx and providing long-term survival of the transplanted organ [2]. The most commonly prescribed immunosuppressive protocol worldwide includes a combination of tacrolimus (Tac), mycophenolic acid (MPA) or mycophenolate mofetil (MMF) and corticosteroid (CS). Status and success of Tx can be attributed to the introduction of calcineurin inhibitors, cyclosporin A (CsA) and Tac, into clinical practice, primarily in terms of reduced incidence of acute rejection and improved short-term graft survival $(90 \%$ in the first post-transplant year) $[1,3,4]$. Tacrolimus is the background of the most immunosuppressive protocols after Tx worldwide, whereas its clinical use is characterized by marked interindividual variability in its pharmacokinetics, narrow therapeutic index and chronic nephrotoxicity $[5,6]$. The pharmacokinetic variability may result in Tac concentrations beyond the optimal therapeutic range $(5-15 \mathrm{ng} / \mathrm{mL})$ and contribute to underimmunosuppression and immunological-mediated transplant rejection or overimmunosuppression and adverse effects and toxicity. Accordingly, therapeutic drug monitoring (TDM) is necessary in order to improve efficacy and reduce the toxicity of Tac $[7,8]$. Investigation of factors contributing to pharmacokinetic variability and application of TDM seems to be more important considering that target therapeutic range of Tac is even narrower than optimal range and dependent to period after Tx. In the present study, Tac concentrations were maintained in target range of $8-12 \mathrm{ng} / \mathrm{mL}$ for the first 90 days and 6-10 ng/mL afterwards.

Tacrolimus is characterized by low bioavailability and extensive presystemic metabolism in the intestine and liver. It is a substrate for the cytochrome P450 3A4 and 3A5 isoenzymes, but also for the P-glycoprotein, an efflux pump, localized on the outer membrane of enterocytes, which takes part in its elimination [5]. Tacrolimus is initially formulated as the immediate-release hard capsule, which is administered twice-a-day, every $12 \mathrm{~h}$
(Tac-twice-daily, Tac-TD). In order to improve patients' adherence and reduce treatment cost, the same manufacturer released another oral formulation of Tac, prolonged-release hard capsule, which is administered once-a-day (Tac-once-daily, Tac-OD) [9]. Studies have shown that non-adherence is one of the dominant causes which contributes to transplant rejection $[10,11]$. However, minor variations in drug bioavailability due to the differences in drug formulation may have significant effects on post-transplant outcomes. The initial dose of both Tac formulations is $0.2-0.3 \mathrm{mg} / \mathrm{kg} / \mathrm{day}$, with Tac-TD divided into two doses (morning and evening), while Tac-OD formulation is administered once-daily in the morning. Although the manufacturer suggests the conversion of Tac-TD with Tac-OD formulation in the ratio of $1 \mathrm{mg}: 1 \mathrm{mg}$, certain studies showed a reduction in drug exposure after conversion and need for the Tac-OD dose increasing in some patients in order to achieve optimal immunosuppression [9].

\section{AIM}

The aim of this study was to compare daily doses, trough concentrations $\left(\mathrm{C}_{0}\right)$ and doseadjusted trough concentrations (C0/D) of Tac between patients who were administered different drug formulations, Tac-TD or Tac-OD, during the first year after Tx. Additionally, the aim of the study was to compare the distribution of $\mathrm{C}_{0}$ within and beyond the target therapeutic range $(8-12 \mathrm{ng} / \mathrm{mL}$ for the first 90 days and $6-10 \mathrm{ng} / \mathrm{mL}$ afterwards) after the administration of different drug formulations.

\section{SUBJECTS AND METHODS}

The academic IV phase, retrospective pharmacokinetic study was conducted at Department of Pharmacy, Faculty of Medicine, University of Nis and the Clinic of Nephrology, Clinical Center Nis. The study was approved by Ethics Committee of Faculty of Medicine University of Nis (No 12-2307-2/5 from 10.03.2016. and No 12-6972-2/5 from 02.07.2018).

\section{Patients}

The study included 84 patients who underwent transplantation surgery between 
2008 and 2016. All patients had their routine controls, including TDM of Tac and biochemical monitoring, at the Clinic of Nephrology, Clinical Center Nis. Chemical name of Tac according to IUPAC is: $(1 \mathrm{R}$, 9S, 12S, 13R, 14S, 17R, 18E,21S,23S,24R,25S,2 7R)-1,14-dihydroxy-12-[1-[(1R,3R,4R)-4-hydroxy-3-methoxycyclohexyl]prop-1-en2-yl]-23,25-dimethoxy-13,19,2 1,27tetramethyl-17-prop-2-enyl-11,28dioxa-4-azatricyclo[22.3.1.04,9] octacos-18-ene-2,3,10,16-tetrone. Patients were prescribed two Tac formulations: conventional preparation, immediate-release hard capsules (Prograf', Astellas Ireland Co. Ltd.) or prolonged-release hard capsules (Advagraf ${ }^{\circ}$, Astellas Ireland Co. Ltd.). Of 84 patients, 56 were administered Tac-TD and 28 were administered Tac-OD. The study involved a period from 1 up to 12 months after Tx, with 753 routine controls $\left(\mathrm{C}_{0}\right.$ was determined) in patients on Tac-TD, and 302 routine controls in patients on Tac-OD. Of all patients enrolled in the study, 53 were men and 31 were women, mean age $40 \pm 11$ at the beginning of the study period (a month after Tx). The data used in the study were taken from the medical records of kidney transplant recipients. In order to protect patient data, each patient was assigned a code at the beginning of the study, which was used in statistical analysis instead of patient's name.

\section{Immunosuppressive protocol}

All patients were prescribed a Tac-based quaternary immunosuppressive protocol after Tx. Besides Tac, it included: intravenous methylprednisolone, with an initial dose of $0.5 \mathrm{~g} /$ day which was later switched to oral CS preparation, prednisone (PRE), initial dose of $1 \mathrm{mg} /$ $\mathrm{kg} /$ day, then MMF 1.5-2 g/day or MPA 1.08$1.44 \mathrm{~g} /$ day orally and $20 \mathrm{mg}$ of monoclonal antibody basiliximab which was administered at the first and the fourth day after Tx. Tac was administered on day 5 post-transplantation with an initial dose of $0.2-0.3 \mathrm{mg} / \mathrm{kg} / \mathrm{day}$ divided into two doses (Tac-TD) or 0.2-0.3 mg/ $\mathrm{kg} /$ day once-daily (Tac-OD). Afterward, Tac was administered twice-daily $(08.00 \mathrm{~h}$ and $20.00 \mathrm{~h}$ ) or once-daily $(08.00 \mathrm{~h})$ depending on the prescribed drug, and the dose was adjusted according to the TDM in order to achieve target therapeutic range of $8-12 \mathrm{ng} / \mathrm{mL}$ for the first 90 days and $6-10 \mathrm{ng} / \mathrm{mL}$ afterwards.
Therapeutic drug monitoring of Tac implies determination of whole-blood $\mathrm{C}_{0}$ concentration, measured at the end of the dosing interval, usually before taking the morning dose (trough concentration).

Besides standard immunosuppressive therapy, patients also received antihypertensive drugs: beta blockers (bisoprolol, metoprolol or carvedilol) and/or calcium channel blockers (amlodipine, lercanidipine, and nifedipine), and rarely angiotensin-converting enzyme (ACE) inhibitors and methyldopa. Patients used gastroprotective drugs: omeprazole, pantoprazole or ranitidine. For the purpose of biochemical monitoring, serum level of glucose (GLU), albumin (ALB), Blood Urea Nitrogen (BUN), creatinine (CRE) and serum activity of aspartate aminotransferase enzyme (AST) and alanine aminotransferase (ALT) were routinely determined. The estimated glomerular filtration rate (eGFR) was calculated by The Modification of Diet in Renal Disease (MDRD) equation.

\section{Pharmacokinetic data}

For the purpose of analysis, the following data were collected: daily dose, daily dose according to patient's body weight, concentration $\mathrm{C}_{0}$ and $\mathrm{C}_{0} / \mathrm{D}$ of Tac. Daily dose was obtained from the medical records or in oral communication with patients, while $\mathrm{C}_{0}$ was measured in the whole blood by the immunoassay method according to the manufacturer's instructions (Architect, Abbott, IL, USA). The value $\mathrm{C}_{0} / \mathrm{D}$ represents the quotient of $\mathrm{C}_{0}(\mathrm{ng} / \mathrm{mL})$ divided by daily dose (mg/day).

\section{Statistical analysis}

The characteristics of the study group were defined as: mean \pm standard deviation and median (interquartile range) or frequency (with or without percentage). Student t-test for independent samples (for normal data distribution) or Mann-Whitney $U$ test (when data normality was not satisfied) were used to compare pharmacokinetic parameters between groups of patients on different Tac formulation. Hi-square $(\chi 2)$ test was used to compare the distribution of concentrations within and beyond the optimal range. Statistical analyses were performed using SPSS statistical software (version 20.0) at the significance level set at $\mathrm{p}$ $<0.05$. 


\begin{tabular}{|c|c|c|c|}
\hline \multirow{2}{*}{ PARAMETERS } & \multicolumn{3}{|c|}{ Period after Tx } \\
\hline & 1-3 month after Tx & 4-6 month after $\mathrm{Tx}$ & 7-12 month after $\mathrm{Tx}$ \\
\hline \multicolumn{4}{|l|}{$\begin{array}{l}\text { DEMOGRAPHIC } \\
\text { CHARACTERISTICS }\end{array}$} \\
\hline Sex (male/ female) & & $53 / 31$ & \\
\hline Donor type (living/deceased) & & $61 / 23$ & \\
\hline Age at the time of Tx (years) & & $\begin{array}{c}40.00 \pm 10.91 \\
39.50(31.25-48)\end{array}$ & \\
\hline Body weight (kg) & $\begin{array}{c}72.09 \pm 15.70 \\
70(62-80)\end{array}$ & $\begin{array}{l}74.73 \pm 16.80 \\
71.40(65-80)\end{array}$ & $\begin{array}{c}75.30 \pm 15.56 \\
72.50(65-81)\end{array}$ \\
\hline BMI $\left(\mathrm{kg} / \mathrm{m}^{2}\right)$ & $\begin{array}{c}24.19 \pm 4.10 \\
23.56(21.72-25.43)\end{array}$ & $\begin{array}{c}25.02 \pm 4.04 \\
24.09(22.35-26.42)\end{array}$ & $\begin{array}{c}25.41 \pm 3.91 \\
24.28(22.54-27.43)\end{array}$ \\
\hline \multicolumn{4}{|l|}{ BIOCHEMICAL PARAMETERS } \\
\hline AST (U/L) & $\begin{array}{c}21.87 \pm 18.24 \\
18(13.30-24)\end{array}$ & $\begin{array}{c}24.46 \pm 20.43 \\
20(16-25.30)\end{array}$ & $\begin{array}{c}24.60 \pm 18.57 \\
20(16-25)\end{array}$ \\
\hline ALT (U/L) & $\begin{array}{c}38.05 \pm 33.22 \\
28(21-40.50)\end{array}$ & $\begin{array}{c}39.43 \pm 52.25 \\
26(18.15-38)\end{array}$ & $\begin{array}{c}37.83 \pm 37.27 \\
26(19-42)\end{array}$ \\
\hline GLU (mmol/L) & $\begin{array}{c}6.23 \pm 3.98 \\
5(4.40-5.80)\end{array}$ & $\begin{array}{c}5.94 \pm 3.14 \\
5.08(4.60-5.80)\end{array}$ & $\begin{array}{c}5.75 \pm 2.54 \\
5.09(4.67-5.70)\end{array}$ \\
\hline BUN (mmol/L) & $\begin{array}{c}8.74 \pm 4.09 \\
8.20(6.40-10.40)\end{array}$ & $\begin{array}{c}8.55 \pm 3.87 \\
7.70(6-9.90)\end{array}$ & $\begin{array}{c}7.87 \pm 3.07 \\
7.30(5.70-9.40)\end{array}$ \\
\hline ALB (g/L) & $\begin{array}{c}39.55 \pm 4.17 \\
39(37-42)\end{array}$ & $\begin{array}{c}40.03 \pm 4.05 \\
40(38-42)\end{array}$ & $\begin{array}{c}41.06 \pm 4.25 \\
41(39-44)\end{array}$ \\
\hline \multicolumn{4}{|l|}{$\begin{array}{l}\text { KIDNEY FUNCTION } \\
\text { PARAMETERS }\end{array}$} \\
\hline \multicolumn{4}{|l|}{ CRE $(\mu \mathrm{mol} / \mathrm{L})$} \\
\hline Tac-TD & $\begin{array}{c}137.70 \pm 40.20 \\
132(107-162)\end{array}$ & $\begin{array}{c}141.68 \pm 43.53 \\
131(110.50-169)\end{array}$ & $\begin{array}{c}136.79 \pm 43.70 \\
127(108-152)\end{array}$ \\
\hline Tac-OD & $\begin{array}{c}145.96 \pm 41.92 \\
144(121-162.50)\end{array}$ & $\begin{array}{c}145.01 \pm 32.45 \\
145(118-163)\end{array}$ & $\begin{array}{c}136.53 \pm 32.97 \\
130.45(113.50- \\
154.50)\end{array}$ \\
\hline \multicolumn{4}{|l|}{ eGFR $\left(\mathrm{mL} / \mathrm{min} / 1.73 \mathrm{~m}^{2}\right)$} \\
\hline Tac-TD & $\begin{array}{c}52.10 \pm 15.92 \\
51.25(41.15-58.61)\end{array}$ & $\begin{array}{c}51.37 \pm 16.28 \\
49.80(40.24-61.04)\end{array}$ & $\begin{array}{c}53.56 \pm 18.91 \\
51.57(41.48-61.69)\end{array}$ \\
\hline Tac-OD & $\begin{array}{c}49.81 \pm 14.05 \\
49.44(41.84-58.99)\end{array}$ & $\begin{array}{c}47.70 \pm 12.05 \\
48.88(38.18-54.63)\end{array}$ & $\begin{array}{c}50.89 \pm 12.46 \\
52.36(43.59-58.98)\end{array}$ \\
\hline
\end{tabular}

\section{RESULTS}

Table 1. shows demographic characteristics and biochemical parameters of the kidney transplant recipients in different periods during the first year after Tx. Of all patients, $63 \%$ were men, while $73 \%$ of patients had living donor kidney transplant. The median age at the time of transplantation was 39.5 years (range: 19-69). The mean values of AST, ALT, GLU, ALB and BUN were within physiological range, while the values of CRE and eGFR indicated the satisfactory function of the transplanted organ for the observed post-transplant period.

Also, there was no difference in CRE and eGFR between defined groups of patients.
In the conducted study, the daily doses of Tac-OD were higher than Tac-TD dur-

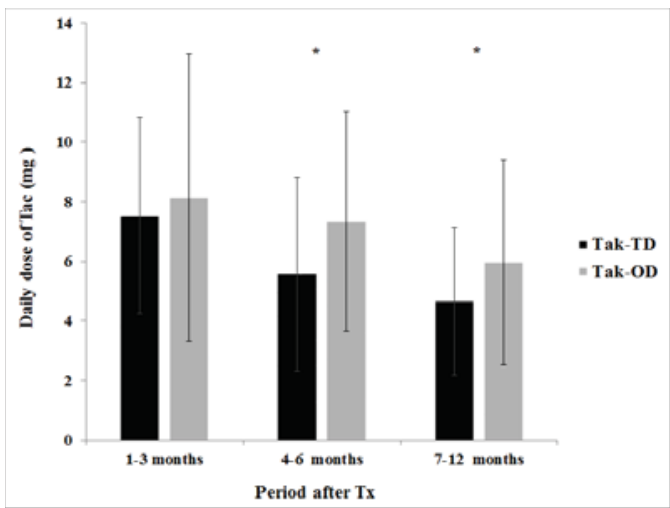

Table 1. Characteristics of the kidney transplant recipients

Data are expressed as mean \pm standard deviation and median (interquartile range) or number of patient

- AST - aspartate aminotransferase;

- ALT - alanine aminotransferase;

- GLU - glucose;

- CRE - serum creatinine level;

- BUN - blood urea nitrogen serum level;

- ALB - serum albumin;

- eGFR - estimated glomerular filtration rate
Figure 1. Daily dose of different Tac formulations during the first year after Tx $\left({ }^{*}: p<0.01\right)$ 
Figure 2. Daily dose per kilogram of different Tac formulations during the first year after Tx $\left({ }^{*}: p<0.01\right)$

Figure 3. Trough concentration of Tac of different Tac preparations during the first year after $\operatorname{Tx}\left({ }^{*}: \mathrm{p}<0.01\right)$

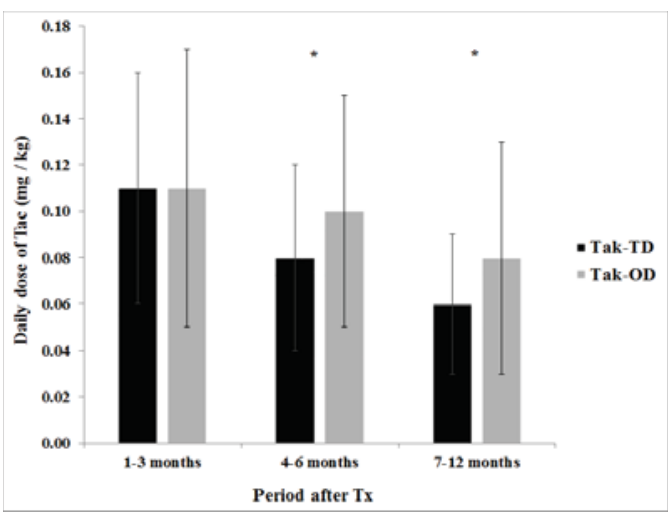

ing 4-6 months $(7.35 \pm 3.68$ vs. $5.56 \pm 3.25 ; Z=-$ 4.457; $\mathrm{p}=0.000)$ and $7-12$ months $(5.97 \pm 3.44$ vs. $4.66 \pm 2.48 ; \mathrm{Z}=-4.011 ; \mathrm{p}=0.000)$ after $\mathrm{Tx}$ (Figure 1). Daily doses of two Tac preparation did not differ significantly during the first three months after $\operatorname{Tx}(8.13 \pm 4.82$ vs. $7.53 \pm 3.30, \mathrm{Z}=-$ $0.108 ; \mathrm{p}=0.914)$.

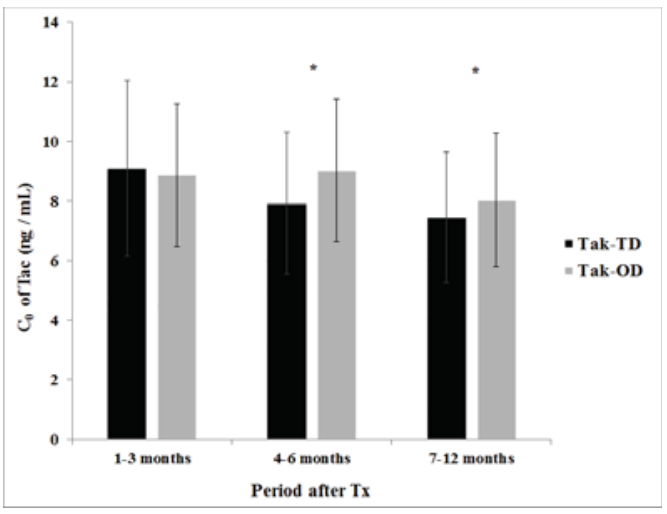

Figure 2. demonstrates the daily doses expressed per kilogram of body weight. There was no difference during the first three months after Tx $(0.11 \pm 0.06$ vs. $0.11 \pm 0.05 ; Z=$ $0.162 ; \mathrm{p}=0.871)$. However, in the period from $4^{\text {th }}$ to $6^{\text {th }}$ month $(0.10 \pm 0.05$ vs. $0.08 \pm 0.04 ; Z=-$ 4.359; $\mathrm{p}=0.000$ ) and during the remaining 6 months after Tx until the end of the study (0.08 \pm 0.05 vs. $0.06 \pm 0.03 ; Z=-4.588 ; p=0.000)$,

Figure 4. Dose-adjusted concentration of Tac of different Tac preparations during the first year after Tx $\left({ }^{*}: p<0.05 ;{ }^{* *}\right.$ : $\mathrm{p}<0.01$ )

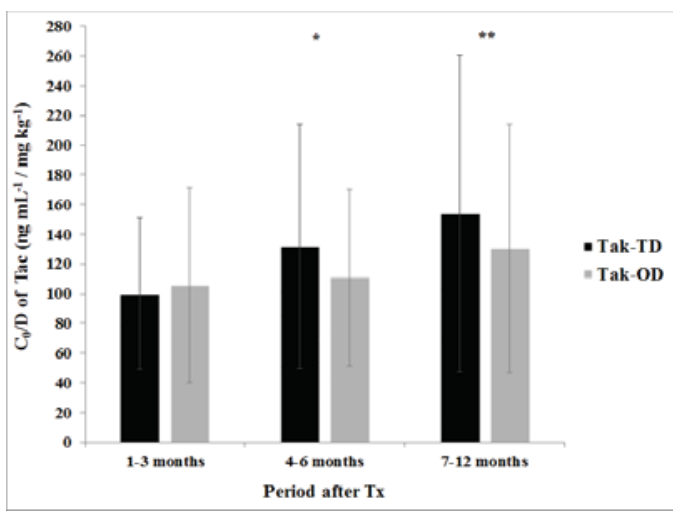

patients on Tac-OD formulation received higher doses compared to patients on Tac-TD formulation.

Figure 3. shows the mean $\mathrm{C}_{0}$ concentrations of Tac measured in patients on different Tac preparation. Same as with the daily dose, patients in the Tac-OD group had higher $\mathrm{C}_{0}$ concentrations than patients in the Tac-TD group in the period from 4th to 6th month (9.03 \pm 2.39 vs. $7.92 \pm 2.38 ; Z=-3.589 ; \mathrm{p}=0.000)$ and during the remaining 6 months until the end of the study $(8.04 \pm 2.25$ vs $7.46 \pm 2.20 ; \mathrm{Z}=$ $2.661 ; \mathrm{p}=0.008)$ after Tx. There was no difference in the examined pharmacokinetic parameter between patient groups in the first three months after Tx $(8.88 \pm 2.40$ vs. $9.10 \pm 2.95 ; Z=-$ $0.414 ; \mathrm{p}=0.679)$.

Tac dose is not constant during the post-transplant period, and everyday practice includes its changing in order to maintain the $\mathrm{C}_{0}$ concentration in the optimal range. Accordingly, a better indicator of drug exposure is dose-adjusted trough concentration, $\mathrm{C}_{0} / \mathrm{D}$. The results of the conducted study showed that kidney transplant recipients who used Tac-OD had lower $\mathrm{C}_{0} / \mathrm{D}$ values compared to patients on Tac-TD both during 4-6 months $(110.65 \pm 59.32$ vs. $131.63 \pm 82.26$; $Z=-$ 2.173; $\mathrm{p}=0.030)$ and $7-12$ months after $\mathrm{Tx}$ $(130.14 \pm 83.78$ vs. $153.74 \pm 106.81 ; Z=-3.100$; $\mathrm{p}=0.002)$. This result may suggest that this group of patients (Tac-OD group) with the same dose may achieve lower concentrations of Tac in the blood. There was no difference in $\mathrm{C}_{0} / \mathrm{D}$ during $1-3$ months $(105.58 \pm 65.57$ vs. 100.14 $\pm 51.15 ; \mathrm{Z}=-0.277 ; \mathrm{p}=0.782)$ after $\mathrm{Tx}$ (Figure 4).

$\mathrm{C}_{0}$ concentrations were measured beyond the optimal range $(5-15 \mathrm{ng} / \mathrm{mL})$ significantly more frequently in patients on Tac-TD formulation compared to patients on Tac-OD formulation ( $9.1 \%$ vs. $4.7 \% ; \chi=6.096 ; \mathrm{p}=0.048$ ) (Figure 5).

Distribution of $\mathrm{C}_{0}$ was different when target range was used instead of optimal therapeutic range, with more concentrations out of the range. Although, Tac-TD patients had more $\mathrm{C}_{0}$ beyond the target range $(8-12 \mathrm{ng} / \mathrm{mL})$ compared to patients on Tac-OD formulation between the $1^{\text {st }}$ and $3^{\text {rd }}$ month post-transplantation, such difference was not significant ( $54.4 \%$ vs. $50 \% ; \chi=0.593 ; p=0.743$ ) (Figure $6 a$ ).

Conversely, statistical significance was observed in distribution of $\mathrm{C}^{0}$ within and beyond target range (6-10 $\mathrm{ng} / \mathrm{mL})$ between 
patients on different Tac formulations from $4^{\text {th }}$ month until the end of the study (Figure 6b). Although, both patient groups had almost the same percentage of $\mathrm{C}_{0}$ within range, Tac-TD patients had significantly more $\mathrm{C}_{0}$ below the range, whereas Tac-OD patients had more $\mathrm{C}_{0}$ above the range $(<6 \mathrm{ng} / \mathrm{mL}: 22.5 \%$ vs. $12.8 \%$; $>10 \mathrm{ng} / \mathrm{mL}: 13.1 \%$ vs. $23.9 \%$; $\chi=19.989$; $\mathrm{p}=0.000)$.

\section{DISCUSSION}

The basic problem of $\mathrm{Tx}$ is immune mediated acute and chronic transplant rejection, which is mediated by T-lymphocytes [1, 3]. Depending on the pharmacological group, immunosuppressive drugs inhibit multiple immunological mechanisms, which consequently result in blocking activation of intracellular mechanisms within T-lymphocytes and release of interleukin-2 (IL-2) and other cytokines. The activation of IL-2 receptor (IL2R) leads to activation of mammalian target of rapamycin (mTOR), thus triggering the proliferation of T-lymphocytes, which are key factors in the process of transplant rejection [2,3]. Tac achieves its effect by inhibiting the activity of calcineurin and consequent blockage of IL-2 transcription and other cytokines that promote the activation and proliferation of $\mathrm{T}$ lymphocytes, thereby preventing the rejection of the transplanted organ [5].

Therapeutic monitoring of Tac is routinely performed for individualization of Tac dose in order to maintain drug efficacy and minimize the consequences of overexposure [12]. Although, it is generally accepted that optimal therapeutic range is $5-15 \mathrm{ng} / \mathrm{mL}$, target range of Tac concentration is narrower and depends on the time after Tx. Before 2008, target concentration was $12-15 \mathrm{ng} / \mathrm{mL}$ during the first month, $10-12 \mathrm{ng} / \mathrm{mL}$ from months $1-12$ and $8-10 \mathrm{ng} / \mathrm{mL}$ after month 12. From 2008. target range was $12-15 \mathrm{ng} / \mathrm{mL}$ during the first month, $10-12 \mathrm{ng} / \mathrm{mL}$ from month $1-3,8-10$ $\mathrm{ng} / \mathrm{mL}$ from months $3-12$ and $6-8 \mathrm{ng} / \mathrm{mL}$ after month 12 [13]. Additionally, target therapeutic range of Tac can be different according to transplantation center. In the study of Gleder et al. data were gained from two prospective randomized multicenter trials (ClinicalTrials.gov: NCT01187953 and NCT01683331), which had different target range of Tac: (1) 6-11 ng/mL for the first 30 days and 4-11 ng/ $\mathrm{mL}$, afterwards and (2) $8-12 \mathrm{ng} / \mathrm{mL}$ for the

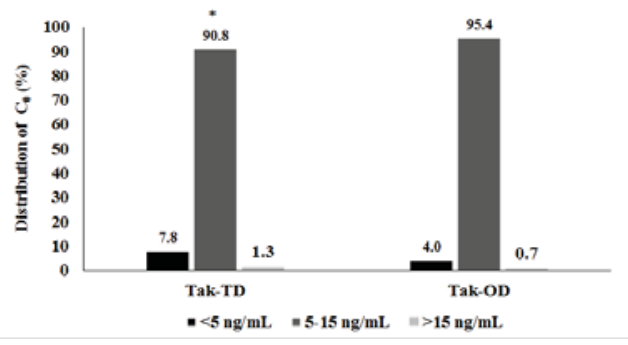

Figure 5. Distribution of $\mathrm{C}_{0}$ concentrations within and beyond the optimal range dependent on the prescribed Tac preparation $\left(^{*}: p<0.05\right)$

*Statistical significance is related to the differences between the two formulations concerning $C_{0}$ values out of the optimal range.

first 90 days, then $5-8 \mathrm{ng} / \mathrm{mL}$ [14]. In the Symphony study, target levels were even lower, between 3 and $7 \mathrm{ng} / \mathrm{mL}$, and demonstrated lower rates of acute rejection and improved graft function as well [15]. Recently, Baker et al. indicated that Tac levels $<4.0 \mathrm{ng} / \mathrm{mL}$ were associated with higher rejection rates in the 'postSYMPHONY' era. Therefore, they proposed

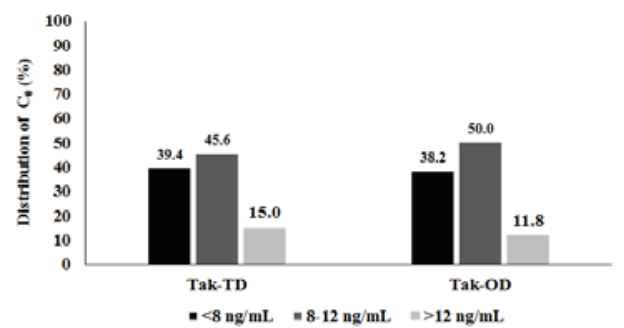

Figure 6a. Distribution of $\mathrm{CO}$ concentrations within and beyond the target range between 1 st and 3rd month post-transplantation dependent on the prescribed Tac preparation

guidelines for trough tacrolimus levels of 4-8 $\mathrm{ng} / \mathrm{mL}$ [16]. In addition, Gatault et al., suggested that in patients on extended formulation of Tac, $\mathrm{C}_{0}$ should kept above $7 \mathrm{ng} / \mathrm{mL}$ during the first postoperative year [17]. Besides, all of these target ranges are mostly recommended for immunoassays, which is method of choice for Tac TDM worldwide. Recently, a docu-

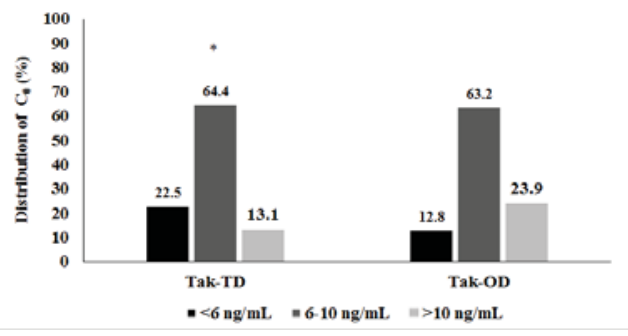

ment entitled: „Clinical Guidelines for Transplant Medications" has suggested target range for liquid chromatography-tandem mass spectrometric detection (LC-MS/MS) TDM method: 8 to $12 \mathrm{ng} / \mathrm{mL}$, less than 1 month after Tx, , 6 to $9 \mathrm{ng} / \mathrm{mL}$, between 1 and 3 months, and 4 to $8 \mathrm{ng} / \mathrm{mL}$, afterwards [18]. LC-MS/MS method is now being increasingly implemented as a cost-effective alternative for Tac TDM.
Figure 6b. Distribution of $\mathrm{CO}$ concentrations within and beyond the target range between 4th and 12th month post-transplantation dependent on the prescribed Tac preparation (*: $\mathrm{p}<0.01$ )

*Statistical significance is related to the differences between the two formulations concerning $C_{0}$ values out of the target range. 
Although, immunoassays have some advantages compared to analytical methods such as quick turnaround time, lower costs, and less complexity, they cross-reactivity with Tac metabolites including 13-O-desmethyl tacrolimus $(10 \%$ of the immunosuppressive activity of Tac) and up to $30 \%$ of Tac quantification may be due to nonspecific detection. Conversely, LC-MS/MS is characterized with higher sensitivity, precision and accuracy compared to immunoassays as well as ability to separate and simultaneously measure Tac concentration and its metabolites. Still, its application in individual centers is limited and immunoassays will remain the backbone of Tac TDM [19].

Previous studies showed significant differences regarding pharmacokinetic parameters between Tac-TD and Tac-OD formulation within the first post-transplantation months. Tac-OD patients when compared to Tac-TD patients, showed higher $\mathrm{AUC}_{0-24}$ (AUC-area under the C-t curve), maximum concentration of Tac (Cmax) and $\mathrm{C}_{0}$ as well as lower daily dose of Tac. Although, those differences were lost later on, it was suggested that TDM and biochemical monitoring should be performed more often in Tac-OD patients after conversion or in de novo kidney transplant recipients on Tac-OD formulation [20]. The equivalent ratio of Tac-TD and Tac-OD formulations in terms of $\mathrm{C}_{0} / \mathrm{AUC}_{0-24}$ provided the same principle considering TDM, i.e. determining $\mathrm{C}_{0}$ and the same target concentration range [21].

The results of our study did not show significant difference in daily doses between examined formulations during the first three post-transplant months. However, after this period, patients in the Tac-OD group used significantly higher doses of Tac in order to maintain optimal immunosuppression. Crespo et al. compared a group of 26 de novo transplanted patients on Tac-OD with the same size group of patients on Tac-TD for up to 6 months after Tx [22]. The authors showed that there was no significant difference in the daily doses between Tac-OD and Tac-TD formulations until the third month after Tx, while in the period between the third and sixth month after Tx, patients on Tac-OD formulation required higher doses to maintain the concentrations within the appropriate range. These findings are in accordance with the results of our study. Moreover, Masutani et al., showed higher administered doses of Tac-OD prepa- ration during 3-12 months after transplantation [23]. On the contrary, Kitada et al. demonstrated significant differences in Tac daily dose between examined preparations in the early period after Tx (up to three months), which was not followed by the same trend at the end of the first year [24].

Similar trend was obtained when instead of daily dose, $\mathrm{C}_{0}$ concentration was compared among patients who used different formulations of Tac (Figure 3). It was shown that there was no difference in $\mathrm{C}_{0}$ over 1-3 months after $\mathrm{Tx}$, whereas, after that period, higher $\mathrm{C}_{0}$ values were measured in the Tac-OD group. An explanation for this result should be that an increase of Tac daily dose was followed by the subsequent increase of blood $\mathrm{C}_{0}$. However, as patients on Tac-based immunosuppression received different doses of Tac, which were often adjusted to the optimal therapeutic range, the drug exposure can be better compared using the $\mathrm{C}_{0} / \mathrm{D}$ parameter instead of $\mathrm{C}_{0}$. Accordingly, our study showed that patients on different Tac preparations had identical exposure during the first three months, while after that period, patients on Tac-OD had lower values of $\mathrm{C}_{0} / \mathrm{D}$ comparing with patients on Tac-TD formulation. This result indicates that patients in the Tac-OD group achieve lower concentrations $\mathrm{C}_{0}$ with the same dose regimen than patients in the Tac-TD group after the third-month post-transplant. Therefore, conversion of Tac-TD with Tac-OD formulation, in the recommended ratio of $1 \mathrm{mg}: 1 \mathrm{mg}$, could contribute to lower concentrations of Tac than expected after switching, with a risk that their values would be below optimal. In contrast to our study, previously conducted researches were mainly comparing different Tac formulations in the early period (within the first month) after Tx $[25,26,27]$. In a multicenter study which included 667 patients examined during the first year after Tx, Kramer et al. showed lower $\mathrm{C}_{0}$ concentrations after the administration of Tac-OD in the early period after Tx, while the concentrations were comparable thereafter [27]. However, most of the published studies compared the exposure of Tac preparations after conversion from TacTD to Tac-OD $[28,29]$. De Jonge et al. in a study involving 284 patients kidney transplant recipients, demonstrated that the conversion from conventional formulation to prolonged release formulation on 1:1 basis resulted in a decrease of $\mathrm{C}_{0}$ concentration and an increase 
of dose requirements in $52.5 \%$ of patients during the first year after Tx [29]. Barreto et al. suggested that conversion made on a 1:1.1 basis, instead of 1:1, seemed advantageous in kidney transplant recipients who required higher Tac blood levels at conversion and in female recipients in order to avoid significant reduction in Tac levels after conversion [30]. The examined Tac formulations differed in terms of daily doses required to maintain optimal immunosuppression, but their efficacy and safety are comparable. In this respect, there is no evidence that favors a particular formulation [31].

On the other hand, Tac-TD patients had significantly more Tac $\mathrm{C}_{0}$ beyond the optimal target range, 5-15 ng/mL, which can be potentially attributed to patient adherence variations. Still, if comparison was made in relation to target therapeutic range, 8-12 ng/ $\mathrm{mL}$ in the first 90 days, Tac-TD had more $\mathrm{C}_{0}$ of the range, but this difference was not significant. Furthermore, in the period between $4^{\text {th }}$ and $12^{\text {th }}$ month, both formulations achieved almost two thirds of the measured $\mathrm{C}_{0}$ within target range $(6-10 \mathrm{ng} / \mathrm{mL})$, which gives no advantage to any of the investigated formulations. However, higher percentage of $\mathrm{C}_{0}$ above the target range in Tac-OD patients was probably associated with the previous result, that patients on Tac-OD had higher $\mathrm{C}_{0}$ compared to patients on Tac-TD (Figure 3). Then, it is likely to have more $\mathrm{C}_{0}$ above the range in this patient group. In addition, more $\mathrm{C}_{0}$ below target range in Tac-TD patients, can be potentially explained by missing doses more often than in Tac-OD patients. Kuypers et al. showed a significantly higher degree of adherence in patients on Tac-OD than patients on Tac-TD [32]. Namely, the percentage of missed doses was $11.7 \%$ of the morning doses and $14.2 \%$ of the evening doses in the Tac-TD group. This is in accordance with the present study, whereas missed evening dose may result in $\mathrm{C}_{0}$ below the target range.

\section{CONCLUSION}

In conclusion, patients on Tac-OD preparation were receiving higher daily doses of Tac compared to patients on Tac-TD preparation after the third-month post-transplant. Still, by comparing the $\mathrm{C}_{0} / \mathrm{D}$, which represents the index of drug bioavailability, patients on TacOD preparation showed lower drug exposure compared to patients on Tac-TD regimen. The conducted research suggests that patients on Tac-OD preparation may require higher daily doses of Tac compared to patients on Tac-TD preparation in order to maintain optimal immunosuppression in the late post-transplant period. Furthermore, patient groups did not significantly differ in distribution of $\mathrm{C}_{0}$ within or beyond target Tac range in the first 90post-transplantation. Later on, $\mathrm{C}_{0}$ in TacTD patients was significantly more frequently below target range as well as significantly less frequently above the target range compared to Tac-OD patients, while both patient groups had equal distribution of $\mathrm{C}_{0}$ within the target range of Tac.

\section{ACKNOWLEDGEMENTS}

This study was supported by grant of Ministry of Education, Science and Technological Development - project number III41018.

\section{CONFLICTS OF INTEREST}

None declared.

\section{REFERENCES}

1. Chapman JR. What are the key challenges we face in kidney transplantation today? Transplant Res 2013; 2(Suppl 1): S1.

2. Steward-Tharp SM, Song YJ, Siegel RM, O'Shea JJ. New insights into $T$ cell biology and $T$ cell-directed therapy for autoimmunity, inflammation, and immunosuppression. Ann N Y Acad Sci. 2010; 1183:123-48.

3. Menon MC, Murphy B. Maintenance immunosuppression in renal transplantation. Curr Opin Pharmacol. 2013; 13: 662-71.

4. Hart A, Smith JM, Skeans MA, Gustafson SK, Wilk AR, Robinson A, et al. OPTN/SRTR 2016 Annual Data Report: Kidney. Am J Transplant. 2018; 18 Suppl 1:18-113.

5. Staatz CE, Tett SE. Clinical pharmacokinetics and pharmacodynamics of tacrolimus in solid organ transplantation. Clin Pharmacokinet. 2004; 43: 62353.

6. Stefanović NZ, Cvetković TP, Jevtović-Stoimenov TM, Ignjatović AM, Paunović GJ, VeličkovićRadovanović RM. Investigation of CYP $3 A 5$ and $A B C B 1$ gene polymorphisms in the long-term following renal transplantation: Effects on tacrolimus exposure and kidney function. Exp Ther Med. 2015; 10: $1149-56$.

7. Press RR, de Fijter JW, Guchelaar HJ. Individu- 
alizing calcineurin inhibitor therapy in renal transplantation-current limitations and perspectives. Curr Pharm Des. 2010; 16:176 -86.

8. Masuda S, Inui K. An up-date review on individualized dosage adjustment of calcineurin inhibitors in organ transplant patients. Pharmacol Ther. 2006; 112: $184-98$

9. Staatz CE, Tett SE. Clinical Pharmacokinetics of Once-Daily Tacrolimus in Solid-Organ Transplant Patients. Clin Pharmacokinet. 2015; 54: 993-1025.

10. Rosenberger J, Geckova AM, van Dijk JP, Nagyova I, Roland R, van den Heuvel WJ, et al. Prevalence and characteristics of noncompliant behaviour and its risk factors in kidney transplant recipients. Transpl Int. 2005; 18: 1072-8.

11. Denhaerynck K, Steiger J, Bock A, SchäferKeller P, Köfer S, Thannberger N, et al. Prevalence and risk factors of non-adherence with immunosuppressive medication in kidney transplant patients. Am J Transplant. 2007; 7: 108-16

12. Wallemacq $P$, Armstrong VW, Brunet $M$, Haufroid V, Holt DW, Johnston A, et al. Opportunities to optimize tacrolimus therapy in solid organ transplantation: report of the European consensus conference. Ther Drug Monit. 2009; 31:139-52.

13. Vanhove $T$, Vermeulen $T$, Annaert P, Lerut $E$, Kuypers DRJ. High Intrapatient Variability of Tacrolimus Concentrations Predicts Accelerated Progression of Chronic Histologic Lesions in Renal Recipients. Am J Transplant. 2016; 16:2954-63.

14. Glander P, Waiser J, Kasbohm S, Friedersdorff F, Peters R, Rudolph B, et al. Bioavailability and costs of once-daily and twice-daily tacrolimus formulations in de novo kidney transplantation. Clin Transplant. 2018; 32: e13311.

15. Ekberg $\mathrm{H}$, Bernasconi $\mathrm{C}$, Tedesco-Silva $\mathrm{H}$, Vítko $S$, Hugo C, Demirbas A, et al. Calcineurin inhibitor minimization in the Symphony study: observational results 3 years after transplantation. Am J Transplant. 2009; 9: 1876-85.

16. Baker RJ, Mark PB, Patel RK, Stevens KK, Palmer $\mathrm{N}$. Renal association clinical practice guideline in post-operative care in the kidney transplant recipient. BMC Nephrol. 2017; 18: 174.

17. Gatault P, Kamar N, Büchler M, Colosio C, Bertrand D, Durrbach A, et al. Reduction of ExtendedRelease Tacrolimus Dose in Low-Immunological-Risk Kidney Transplant Recipients Increases Risk of Rejection and Appearance of Donor-Specific Antibodies: A Randomized Study. Am J Transplant. 2017; 17: 1370-9.

18. [Internet]. Transplant.bc.ca. 2019 [cited 12 April 2019]. Available from: http://www.transplant.bc.ca/Documents/Health\%20Professionals/ Clinical\%20guidelines/Clinical\%20Guidelines\%20 for\%20Transplant\%20Medications.pdf

19. Andrews LM, Li Y, De Winter BCM, Shi YY, Baan
CC, Van Gelder T, et al. Pharmacokinetic considerations related to therapeutic drug monitoring of tacrolimus in kidney transplant patients. Expert Opin Drug Metab Toxicol. 2017; 13:1225-36.

20. Nemanja Rančić, Viktorija Dragojević-Simić. Comparative pharmacokinetic characteristics of tacrolimus following application of its different pharmaceutical formulations in humans. Рационална терапија 2017; 9: 39-44.

21. Barraclough KA, Isbel NM, Johnson DW, Campbell SB, Staatz CE. Once- versus twice-daily tacrolimus: are the formulations truly equivalent? Drugs. 2011;71: 1561-77.

22. Crespo M, Mir M, Marin M, Hurtado S, Estadella C, Guri ' $X$, et al. De novo kidney transplant recipients need higher doses of Advagraf compared with Prograf to get therapeutic levels. Transplant Proc. 2009; 41:2115-7.

23. Masutani K, Tsuchimoto A, Haruyama N, Kitada $\mathrm{H}$, Okabe $\mathrm{Y}$, Noguchi $\mathrm{H}$, et al. Protocol biopsy findings in living donor kidney transplant patients treated with once-daily or twice-daily tacrolimus formulation. Transplant Proc. 2014; 46: 395-9.

24. Kitada H, Okabe $\mathrm{Y}$, Nishiki T, Miura Y, Kurihara K, Terasaka S, et al. One-year follow-up of treatment with once-daily tacrolimus in de novo renal transplant. Exp Clin Transplant. 2012; 10: 561-7.

25. Andrés A, Delgado-Arranz M, Morales E, Dipalma T, Polanco N, Gutierrez-Solis E, et al. Extendedrelease tacrolimus therapy in de novo kidney transplant recipients: single-center experience. Transplant Proc. 2010; 42(8):3034-7.

26. Wlodarczyk Z, Squifflet JP, Ostrowski M, Rigotti P, Stefoni S, Citterio F, et al. Pharmacokinetics for once- versus twice-daily tacrolimus formulations in de novo kidney transplantation: a randomized, open-label trial. Am J Transplant. 2009; 9: 2505-13.

27. Krämer BK, Charpentier B, Bäckman L, Silva HT Jr, Mondragon-Ramirez G, Cassuto-Viguier E, et al. Tacrolimus once daily (ADVAGRAF) versus twice daily (PROGRAF) in de novo renal transplantation: a randomized phase III study. Am J Transplant. 2010; 10: $2632-43$

28. Caillard S, Moulin B, Buron F, Mariat C, Audard V, Grimbert P, Marquet P. Advagraf $\left({ }^{\circledR}\right)$, a once-daily prolonged release tacrolimus formulation, in kidney transplantation: literature review and guidelines from a panel of experts. Transpl Int. 2016; 29: 860-9.

29. de Jonge $H$, Kuypers DR, Verbeke K, Vanrenterghem Y. Reduced $\mathrm{CO}$ concentrations and increased dose requirements in renal allograft recipients converted to the novel once-daily tacrolimus formulation Transplantation. 2010; 90: 523-9.

30. Barreto P, Malheiro J, Vieira P, Pedroso S, Almeida M, Martins LS, et al. Conversion From TwiceDaily to Once-Daily Tacrolimus in Stable Kidney Graft Recipients. Transplant Proc. 2016; 48: 2276-9. 
31. Noble J, Jouve T, Rostaing L, Malvezzi P. Advagraf $\circledast$ with or without an induction therapy for de novo kidney-transplant recipients. Expert Rev Clin Immunol. 2018; 14: 461-7.

32. Kuypers DRJ, Peeters PC, Sennesael JJ, Kianda $M N$, Vrijens B, Kristanto P, et al. Improved adherence to tacrolimus once-daily formulation in renal recipients: a randomized controlled trial using electronic monitoring. Transplantation. 2013;95: 333-40. 


\title{
Uticaj različitih formulacija takrolimusa na dozni režim i izloženost leka tokom prve godine nakon transplantacije bubrega
}

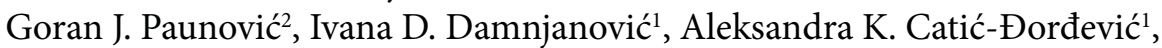 \\ Radmila M. Veličković-Radovanović ${ }^{1,2}$ \\ ${ }^{1}$ Katedra Farmacija, Medicinski fakultet, Univerzitet u Nišu, Niš, Srbija \\ ${ }^{2}$ Klinika za nefrologiju, Klinički centar Niš, Niš, Srbija \\ ${ }^{3}$ Katedra Biohemija, Medicinski fakultet, Univerzitet u Nišu, Niš, Srbija \\ ${ }^{4}$ Medicinski fakultet, Univerzitet u Nišu, Niš, Srbija \\ ${ }^{5}$ Katedra Interna medicina, Medicinski fakultet, Univerzitet u Nišu, Nišs, Srbija
}

Nikola Z. Stefanović ${ }^{1}$, Tatjana P. Cvetković ${ }^{2,3}$, Katarina S. Dinić ${ }^{4}$, Branka P. Mitić ${ }^{2,5}$,

\section{KRATAK SADRŽAJ}

Uvod: Najčešće farmaceutsko-tehnološke formulacije takrolimusa (Tac) koje se primenjuju nakon transplantacije bubrega (Tx) su preparat sa trenutnim oslobađanjem lekovite supstance, primenjuje se dva puta dnevno (Tac-twice-daily, Tac-TD) i preparat sa produženim oslobađanjem lekovite supstance, primenjuje se jednom dnevno (Tac-once-daily, Tac-OD).

Cilj: Cilj rada je bio poređenje dnevne doze, minimalne koncentracije $\left(C_{0}\right)$ i koncentracije korigovane dozom ( $\left.C_{0} / D\right)$ Tac između pacijenata koji su primenjivali različite formulacije leka, Tac-TD ili Tac-OD, u toku prve godine nakon Tx. Dodatno, cilj rada je bio poređenje distribucije $C_{0}$ unutar i izvan ciljnog terapijskog opsega $(8-12 \mathrm{ng} / \mathrm{mL} \mathrm{u}$ prvih 90 dana i 6-10 $\mathrm{ng} / \mathrm{mL}$ posle tog perioda) nakon primene različitih preparata leka. Ispitanici i metode: Retrospektivno farmakokinetičko istraživanje je obuhvatalo 84 pacijenta (56 na Tac-TD i 28 na Tac-OD), pri čemu je period praćenja bio između prvog i dvanaestog meseca nakon Tx. Od farmakokinetičkih podataka korišćeni su: dnevna doza, dnevna doza izražena prema telesnoj težini pacijenta, koncentracija $\mathrm{C}_{0}$ i $\mathrm{C}_{0} / \mathrm{D}$ Tac.

Rezultati: Rezultati istraživanja su pokazali da su pacijenti na Tac-OD preparatu imali veće dnevne doze i više $C_{0}$ leka u periodu 4-6 meseci $(p<0.01)$ i 7-12 meseci $(p<0.01)$ nakon Tx. Takođe, pacijenti na Tac-OD su imali niže $C_{0} / D$ leka u periodu 4-6 meseci $(p<0.05)$ i 7-12 meseci $(p<0.01)$ nakon Tx. Pacijenti na Tac-TD preparatu su imali više $\mathrm{C}_{0}$ ispod ciljnog opsega, a pacijenti na Tac-OD preparatu su imali više $\mathrm{C}_{0}$ iznad ciljnog opsega, dok su obe grupe pacijenata imali istovetnu distribuciju $\mathrm{C}_{0}$ unutar opsega $u$ periodu između 4. i 12. meseca nakon $T x(p<0.01)$.

Zaključak: Sprovedeno istraživanje ukazuje da su pacijenti na Tac-OD zahtevali veće dnevne doze Tac u poređenju sa pacijentima na Tac-TD preparatu u cilju odrežanja optimalne imunosupresije u kasnijem periodu nakon Tx.

Ključne reči: takrolimus, terapijski monitoring leka, farmakokinetička analiza, formulacija sa produženim oslobađanjem 